\title{
硫酸溶液中における鉄および鉄酸化物の陽極挙動
}

\author{
前川立夫** 中島宣 雄**
}

\section{Anodic Behaviors of Iron and Its Oxides in Sulfuric Acid Solutions}

\author{
Tatsuo Maekawa and Nobuo Nakajima
}

Anodic behaviors of pure iron and its oxides in $0.1 \sim 36 \mathrm{~N}$ sulfuric acid solution have been investigated by a potentiostatic method. In the anodic polarization curves of pure iron five current peaks were detected. Although the potentials for these peaks were not affected so large by sulfuric acid concentrations except in the ranges of $12 \sim 16 \mathrm{~N}$ and $28 \sim 32 \mathrm{~N}$, the current densities at the peaks and in the passive region changed complicatedly. On these anodic phenomena, effects of $\mathrm{H}^{+}, \mathrm{HSO}_{4}^{-}$, $\mathrm{SO}_{4}^{2-}$ and undissociated sulfuric acid were discussed.

\section{1. 緒言}

鉄の陽極挙動については, 今まで非常に多くの研究が なされてきたが，その挙動がきわめて複雑なため，その 機構の統一的な解釈は困難であった。筆者らは, 先に比 較的うすい硫酸とアルカリ中の鉄の陽極挙動を, 各種酸 化鉄のそれと比較対照させることにより，その挙動の 機構をある程度明らかにすることができた1)。すなわ ち, 鉄の陽極酸化は, $\mathrm{Fe} \rightarrow \mathrm{FeO}_{1.05} \rightarrow \mathrm{FeO}_{1.1} \rightarrow \mathrm{Fe}_{3} \mathrm{O}_{4} \rightarrow \gamma-$ $\mathrm{Fe}_{2} \mathrm{O}_{3}$ の過程に従って進行し, $1 \mathrm{~N} \mathrm{H}_{2} \mathrm{SO}_{4}$ 中の不働態 化電位は $\mathrm{FeO}_{1.05} / \mathrm{FeO}_{1.1}$ の酸化還元電位に相当するこ とを推察した。従来,一般に鉄の陽極挙動は, 八ロゲン のような特殊なイオンが存在しないかぎ， $\mathrm{pH}$ のみに よって影響を受けるといわれてきたが，最近の研究報告 によると，その他の分極環境によっても顕著な影響を受 け，鉄イオンの存在 ${ }^{2)}$ あるいは硫酸イオン濃度の变化 ${ }^{3)}$ 等によっても Flade 電位あるいは不働態化電位が著し い影響を受けたり, 濃い硫酸中では, 希薄な硫酸中と全
く異なった挙動を示すこと年等が報告されている。筆者 らは鉄の分極特性に及ぼす溶液の影響を調べるため, 種 々の䟴度の硫酸溶液中の鉄ならびに鉄酸化物の陽極挙動 を調べ，これに及ぼす硫酸濃度の影響を検討して，鉄の 陽極酸化過程を確認することを試みた。

\section{2. 試料および実験方法}

本実験に使用した試料は，先の鉄とその酸化物の陽極 特性についての研究1)に用いたものと同じものである。 すなわち純鉄は $0.01 \% \mathrm{C}, 0.01 \% \mathrm{Si}, 0.02 \% \mathrm{Mn}, 0.01$ $\% \mathrm{P}, 0.02 \% \mathrm{~S}$ の不純物を含むものである。また各種鉄 酸化物は $\mathrm{Fe}-\mathrm{O}$ 系平衡状態図5) を参照し, $\mathrm{Fe}$ と $\alpha-\mathrm{Fe}_{2}$. $\mathrm{O}_{3}$ を混合圧搾 $\left(1 \mathrm{t} / \mathrm{cm}^{2}\right)$ したのち， $1,050^{\circ} \mathrm{C}$ で 3 時間 真空焼結 $\left(10^{-2} \mathrm{mmHg}\right) し ，$ 急冷して作製した。このよう にして作った鉄酸化物の表面層は内部と異なっている可 能性があるので, 実験には中心部を使用した。目成した 鉄酸化物の $\mathrm{X}$ 線回折結果を表 1 に示す。表中の酸化物の 酸素含有量は $\mathrm{Fe}$ と $\mathrm{Fe}_{2} \mathrm{O}_{3}$ との混合比から決定したもの

表 1 合成した鉄酸化物の X 線回折結果

\begin{tabular}{|c|c|c|c|c|c|c|c|c|c|c|c|c|c|c|c|c|c|c|c|c|}
\hline \multicolumn{3}{|c|}{ 面 指 数 } & \multicolumn{2}{|c|}{$\mathrm{FeO}_{1.0}$} & \multicolumn{2}{|c|}{$\mathrm{FeO}_{1.025}$} & \multicolumn{2}{|c|}{$\mathrm{FeO}_{1.05}$} & \multicolumn{2}{|c|}{$\mathrm{FeO}_{1.075}$} & \multicolumn{2}{|c|}{$\mathrm{FeO}_{1.1}$} & \multicolumn{2}{|c|}{$\mathrm{FeO}_{1.15}$} & \multicolumn{2}{|c|}{$\mathrm{FeO}_{1.2}$} & \multicolumn{2}{|c|}{$\mathrm{FeO}_{1.25}$} & \multicolumn{2}{|c|}{$\mathrm{FeO}_{1.33}$} \\
\hline $\mathrm{Fe}$ & $\mathrm{FeO}$ & $\mathrm{Fe}_{5} \mathrm{O}_{4}$ & $d$ & $\mathrm{I} / \mathrm{I}_{1}$ & $d$ & $\mathrm{I} / \mathrm{I}_{\mathbf{l}}$ & $d$ & $\mathrm{I} / \mathrm{I}_{1}$ & $d$ & $\mathrm{I} / \mathrm{I}_{1}$ & $d$ & $\mathrm{I} / \mathrm{I}_{1}$ & $d$ & $\mathrm{I} / \mathrm{I}_{1}$ & $d$ & $\mathrm{I} / \mathrm{I}_{1}$ & $d$ & $I_{i} I_{1}$ & $d$ & \\
\hline- & - & & - & - & 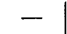 & - & - & & & & - & 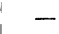 & & - & & & & & & \\
\hline z & & & $=$ & ב & 二 & - & $=$ & ב & & - & & 二 & & $\begin{array}{r}7 \\
18\end{array}$ & & $\begin{array}{l}27 \\
\varepsilon 0\end{array}$ & $\begin{array}{l}2.97 \\
2.527\end{array}$ & $\begin{array}{r}31 \\
100\end{array}$ & .98 & \\
\hline 二 & (111) & & 2.486 & 59 & 2.486 & 100 & 2.486 & 67 & 2.486 & 64 & 2.481 & 65 & 2.475 & 52 & 2.486 & 48 & 2.475 & 20 & 2.532 & \\
\hline 二 & (200) & & 2.155 & 100 & 2.154 & 95 & 2.154 & 86 & 2.150 & 100 & 2. 151 & 100 & 2.146 & 100 & & 100 & & & 2.426 & 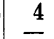 \\
\hline$\overline{1110}$ & - & (400) & & & & & 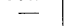 & & - & & 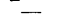 & & 2.0 & 7 & 2.1 & 19 & 2.095 & 23 & 2.102 & 25 \\
\hline (110 & 二 & $(\overline{42} 2)$ & 2.027 & 11 & 2.028 & 6 & - & - & - & - & - & 一 & - & 一 & $\overline{70}$ & $\overline{6}$ & & - & & \\
\hline - & - & $(333)(511)$ & - & - & - & - & - & & - & - & & - & 1.613 & 5 & & 17 & & 26 & $\begin{array}{l}\text { 1. } 714 \\
1.614\end{array}$ & \\
\hline- & (220) & $\overline{(14} 0)$ & 1.522 & 75 & 1.522 & 52 & 1.522 & 100 & 1.520 & 45 & 1.520 & 52 & & 62 & & 41 & 1. 514 & 2 & -1 & \\
\hline & (331) & (7to) & 1.297 & 11 & 1.297 & 16 & 1.297 & 16 & 1.296 & 16 & 1.295 & 13 & & 11 & & 8 & 1.2 & 4 & 1.483 & \\
\hline & (222) & - & 1.242 & 15 & 1.242 & 10 & & & 1.241 & & & 16 & 1.237 & 13 & 1.237 & 8 & 1.2 & & & \\
\hline \multicolumn{3}{|c|}{ 相 } & \multicolumn{2}{|c|}{$\mathrm{Fe}+\mathrm{FeO}$} & \multicolumn{2}{|c|}{$\mathrm{Fe}+\mathrm{FeO}$} & \multicolumn{2}{|c|}{$\mathrm{FeO}$} & \multicolumn{2}{|c|}{$\mathrm{FeO}$} & \multicolumn{2}{|c|}{$\mathrm{FeO}$} & \multicolumn{2}{|c|}{$\mathrm{FeO}+\mathrm{Fe}_{s} \mathrm{O}_{4}$} & \multicolumn{2}{|c|}{$\mathrm{FeO}_{+} \mathrm{Fe}_{3} \mathrm{O}_{4}$} & \multicolumn{2}{|c|}{$\mathrm{FeO}_{+} \mathrm{Fe}_{3} \mathrm{O}_{4}$} & \multicolumn{2}{|c|}{$\mathrm{Fe}_{2} \mathrm{O}_{4}$} \\
\hline \multicolumn{2}{|c|}{ 格子定数 } & $\begin{array}{l}\mathrm{FeO} \\
\mathrm{Fe} \mathrm{O}_{4}\end{array}$ & \multicolumn{2}{|c|}{ 4. 302} & \multicolumn{2}{|c|}{ 4. 302} & \multicolumn{2}{|c|}{4.302} & \multicolumn{2}{|c|}{ 4. 299} & \multicolumn{2}{|c|}{ 4. 295} & \multicolumn{2}{|c|}{$\begin{array}{l}4.285 \\
8.389\end{array}$} & \multicolumn{2}{|c|}{$\begin{array}{l}4.285 \\
8.389\end{array}$} & \multicolumn{2}{|c|}{$\begin{array}{l}4.285 \\
8.389\end{array}$} & \multicolumn{2}{|c|}{$8 . \overline{389}$} \\
\hline
\end{tabular}

* 昭和 39 年 10 月 15 日 第 11 回窝食防食討論会(仙台)において発表

** 三菱原子力工業(株)研究所(埼玉県大宮市北袋町 1 丁目 297 番地) 
であるが，X線回折結果からも妥当なものであることが わかる。すなわち $\mathrm{FeO}_{1.0}$ と $\mathrm{FeO}_{1.025}$ には $\mathrm{Fe}$ と Wüstite の 2 相が, $\mathrm{FeO}_{1.05}, \mathrm{FeO}_{1.075}$ と $\mathrm{FeO}_{1.1}$ には Wüstite 相のみが, $\mathrm{FeO}_{1.20}$ と $\mathrm{FeO}_{1.25}$ には Wüstite と $\mathrm{Fe}_{3} \mathrm{O}_{4}$ の 2 相が存在する。Wüstite 相の格子定数は $\mathrm{Fe}$ と共存す る場合の $4.302 \AA$ から $\mathrm{Fe}_{3} \mathrm{O}_{4}$ と共存する場合の 4.285 A まで, 酸素量の増加に伴って減少している。 $\mathrm{FeO}-$ $\mathrm{Fe}_{3} \mathrm{O}_{4}$ の電気伝導度は十分高く, 分極特性の測定に支障 をきたすことはなかった。これら酸化物のペレットにリ 一ド線を接着したのち，樹脂にうめこみ，エメリー紙 \#1000 まで研摩して電極とした。また，試料内部への 電解液の浸透を防ぐため，パラフィンを含浸させた。純 鉄電極はリード線(鉄線)を点溶接し，エメリ一紙 \#1000 研摩しアセトンで洗浄した。試片表面積を 0.25 あるい は $1 \mathrm{~cm}^{2}$ とし，他をピセインで被覆した。なお硫酸濃 度が高くなると，樹脂，ピセインともに侵されるので， さらにダイフロングリースで被覆した。電解溶液には $20^{\circ} \mathrm{C}$ の $0.1 \mathrm{~N} \sim 36 \mathrm{~N}$ の硫酸溶液を用い，測定を始める 15 分前から窒素を通じ溶存酸素を除き, 測定中は 0.2 $l / \mathrm{min}$ の窒素を通じ，これによって溶液を㨨拌するよ うにした。分極測定に入る前に陰極処理を行ない，回路 を切った後, ほぼ一定電位に落ち着くまで放置し, この 落ち着いた電位を自然電極電位とした。分極測定は自然 電極電位付近から 始め, $20 \mathrm{mV}$ 間隔で電位を貴方向に 移し各電位に 1 分間保持後の電流值を 読 み, 電位-電流 曲線を求めた。また逆に高電位から低電位へと電位を下 げている場合にも同様の手順で測定を行なった。測定装 置は柳本製ポテンショスタット：VE-100 型（電流容 量： $100 \mathrm{~mA}$, 応答速度：10-1 sec）を用いた。この報文 中の電位はすべて飽和甘录電極基準とした。

\section{1 鉄酸化物の陽極分極曲線}

$1 \mathrm{~N}_{2} \mathrm{SO}_{4}$ 中で得られた各種鉄酸化物の陽極分極曲線 を图 1 亿示す。これによると共存 $\mathrm{Fe}$ を含む $\mathrm{FeO}_{1.0}$ には 四つの電流のピーク (図中 $E_{1}, E_{2}, E_{3}, E_{4}$ ) が認められる が，Wüstite 単一相である $\mathrm{FeO}_{1.1}$ になると $E_{1}$ のピー クが認められなくなる。更に $\mathrm{FeO}_{1.1}$ になると $E_{1}, E_{2}$ の 二つのピークが, $\mathrm{Fe}_{3} \mathrm{O}_{4}$ になると $E_{1}, E_{2}, E_{3}$ の三つの ピークが認められなくなる。これらの酸化物の陽極挙動 はすでに前報1)にて検討し,電位-電流曲線上に電流のピ ークが現われるこの四つの電位は $\mathrm{Fe} / \mathrm{FeO}_{1.05}, \mathrm{FeO}_{1.05} /$ $\mathrm{FeO}_{1.1}, \mathrm{FeO}_{1.1} / \mathrm{Fe}_{3} \mathrm{O}_{4}, \quad \mathrm{Fe}_{3} \mathrm{O}_{4} / \mathrm{Fe}_{2} \mathrm{O}_{3}$ の四つの酸化還元 電位を示していることを明らかにした。0.1 $\mathrm{N} \mathrm{H}_{2} \mathrm{SO}_{4}$ 中 でも， $1 \mathrm{~N}_{2} \mathrm{SO}_{4}$ 中でのそれと全く同形の分極曲線が得 られるが，それぞれのピークが現われる電位が 50〜100 $\mathrm{mV}$ 果方向一移行し, 溶解電流が減少する。 $4 \mathrm{~N}, 8 \mathrm{~N}$, $12 \mathrm{~N}, 16 \mathrm{~N} \mathrm{H}_{2} \mathrm{SO}_{4}$ 中で得られた $\mathrm{FeO}_{1.0}$ の陽極分極曲線

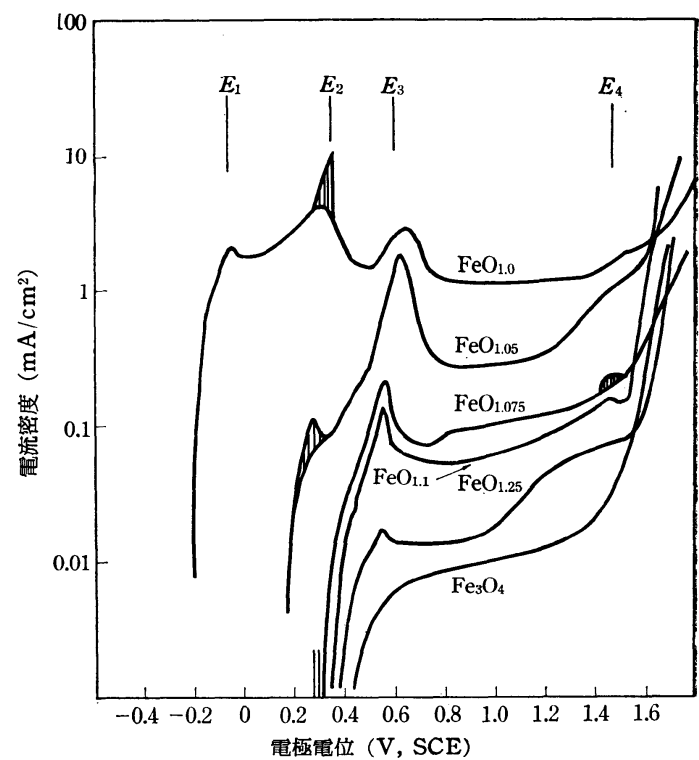

図 $11 \mathrm{~N} \mathrm{H}_{2} \mathrm{SO}_{4}$ 中における鉄酸化物の陽極分極曲線

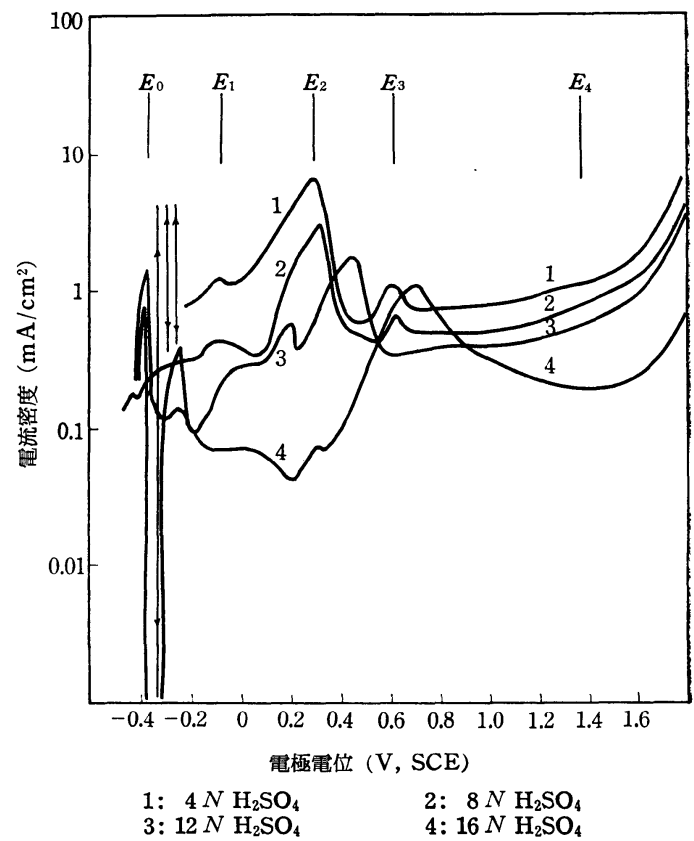

図 $24 N, 8 N, 12 N, 16 N \mathrm{H}_{2} \mathrm{SO}_{4}$ 中における $\mathrm{FeO}_{1.0}$ の陽極分極曲線

を図 2 に示す。 $1 \mathrm{~N} \mathrm{H}_{2} \mathrm{SO}_{4}$ 中における $\mathrm{FeO}_{1.0}$ の自然電 極電位が $-0.21 \mathrm{~V}$ であったのに対してこの濃度範囲の 硫酸中ではかなり低い $-0.5 \mathrm{~V}$ 付近の自然電極電位を 示し, $-0.4 \mathrm{~V}$ 付近に今一つのピーク ( $E_{0}$ と記す) が認 められる。 $4 \mathrm{NH}_{2} \mathrm{SO}_{4}$ 中では $E_{0} \sim E_{1}$ の電位領域で周期 的に電流の大きな振動が認められた。また $4 \mathrm{~N}, 8 \mathrm{NH}_{2}$. $\mathrm{SO}_{4}$ 中では $E_{2}$ のピークが他のピークよりも大きく明瞭 に認められるのに対して, $12 \mathrm{~N}, 16 \mathrm{~N} \mathrm{H}_{2} \mathrm{SO}_{4}$ 中では $E_{3}$ 
のピークが最も大きく現われる。なお $12 \mathrm{~N} \mathrm{H}_{2} \mathrm{SO}_{4}$ 中に おいては $E_{2}, E_{3}$ のピークが車電位方向に移動し, また 一 $0.24 \mathrm{~V}$ に他の濃度に見られないピークが認められる。 この $-0.24 \mathrm{~V}$ のピークは $E_{1}$ がずれたものと思われる。 これらの $12 \mathrm{~N}$ と $16 \mathrm{~N}$ の $\mathrm{H}_{2} \mathrm{SO}_{4}$ 中における異常な挙 動に関しては後で考察する。図 3 に $20 \mathrm{~N}, 24 \mathrm{~N}, 28 \mathrm{~N}$, $32 \mathrm{~N}, 36 \mathrm{~N} \mathrm{H}_{2} \mathrm{SO}_{4}$ 中で得られた $\mathrm{FeO}_{1.0}$ の陽極分極曲線 を示す。 $20 \mathrm{~N}$ 以上の濃度になると $\mathrm{FeO}_{1.0}$ の自然電極電 位は $0.3 \mathrm{~V}$ 付近になり, $i 20 \mathrm{~N}$ 以上の $\mathrm{H}_{2} \mathrm{SO}_{4}$ 中での

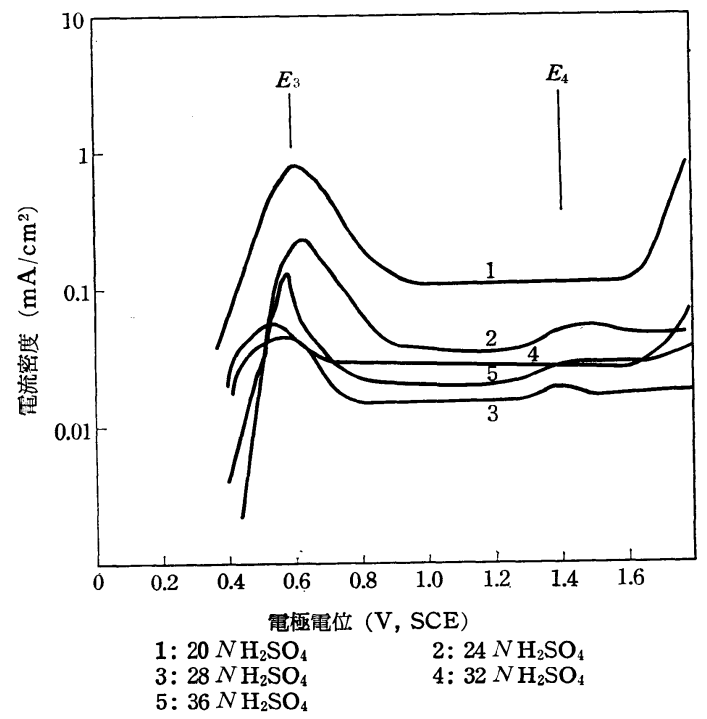

図 $320 \mathrm{~N}, 24 \mathrm{~N}, 28 \mathrm{~N}, 32 \mathrm{~N}, 36 \mathrm{~N} \mathrm{H}_{2} \mathrm{SO}_{4}$ 中に おける $\mathrm{FeO}_{1.0}$ の陽極分極曲線

$\mathrm{FeO}_{1.0}$ の陽分極曲線には $E_{3}$ と $E_{4}$ のピークのみしか観 察されない。これは $E_{2}$ までの酸化反忘が浸漬しただけ で進行してしまうことを意味している。また $28 \mathrm{~N}$ と $32 \mathrm{~N}$ の $\mathrm{H}_{2} \mathrm{SO}_{4}$ 中では $E_{3}$ のピークが他の濃度の硫酸中 のものほど鋭く現われず, 他の濃度中のものと少し異な った挙動を示している。

\section{2 純鉄の陽極分極曲線}

図 4 に $0.1 \mathrm{~N}, 1 \mathrm{~N}, 4 \mathrm{~N}, 8 \mathrm{~N} \mathrm{H}_{2} \mathrm{SO}_{4}$ 中で得られた純鉄 の陽極分極曲線を示す。この濃度範囲の硫酸中での分極 曲線はすでに測定されており, 1 $8 \mathrm{~N} \mathrm{H}_{2} \mathrm{SO}_{4}$ 中での不働 態化電位は $0.3 \mathrm{~V}$ 付近であることが報告されている。こ の電位は $E_{2}$ に相当する。純鉄の場合にも鉄酸化物の場 合と同じく, $0.6 \mathrm{~V}$ 付近と $1.4 \mathrm{~V}$ 付近に $E_{3}$ と $E_{4}$ のピ 一クが認められる。硫酸が希薄になり $0.1 \mathrm{NH}_{2} \mathrm{SO}_{4}$ に なると $1.4 \mathrm{~V}$ 付近まで不働態化されないが，これは実 験方法 (電位送り速度, 前処理等) によって大きな影響 を受ける。しかし一度不働態化したものは，この電位よ り低い電位でも安定で，電位を下げていくと $1.35 \mathrm{~V}$, $0.6 \mathrm{~V}$ にピークが現われ， $0.4 \mathrm{~V}$ 付近で活性化する。こ のことに関しては塭原ら ${ }^{3)}$ にっても報告されている。

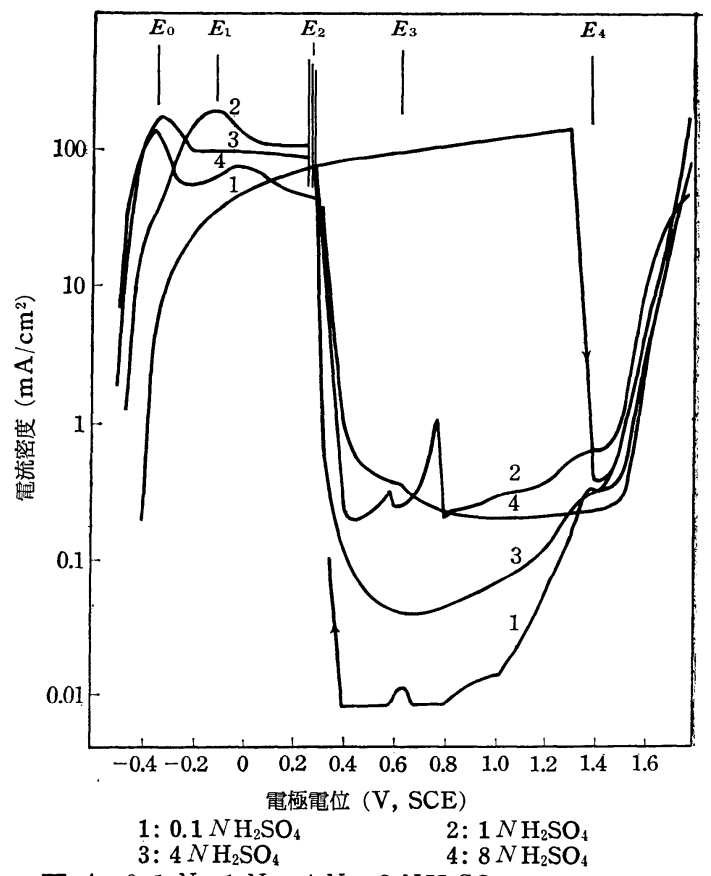

図 $40.1 \mathrm{~N}, 1 \mathrm{~N}, 4 \mathrm{~N}, 8 \mathrm{NH}_{2} \mathrm{SO}_{4}$ 中における純 鉄の陽極分極曲線

$4 \mathrm{~N}$ 以上の濃度の硫酸中では $-0.35 \sim-0.4 \mathrm{~V} に E_{0}$ の ピークが認められる。このピークは濃い硫酸中でのみあ らわれるので硫酸第一鉄の生成によるものと思われる。 図 5 に $10 \mathrm{~N}, 12 \mathrm{~N}, 16 \mathrm{~N} \mathrm{H}_{2} \mathrm{SO}_{4}$ 中で得られた純鉄の陽 極分極曲線を示声。10 $\mathrm{N} \mathrm{H}_{2} \mathrm{SO}_{4}$ では激しい振動現象を

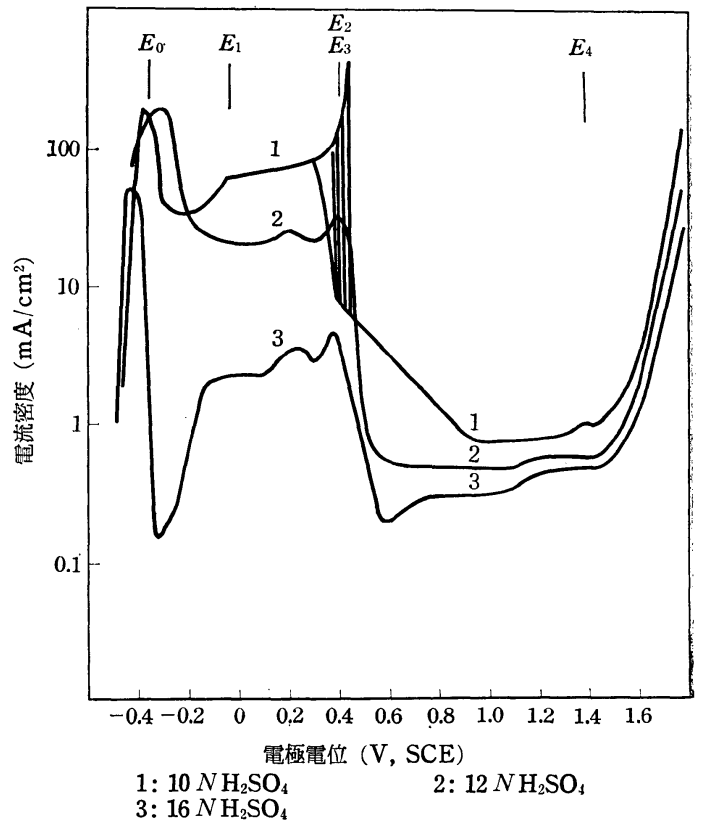

図 $510 \mathrm{~N}, 12 \mathrm{~N}, 16 \mathrm{NH}_{2} \mathrm{SO}_{4}$ 中における純鉄の 陽極分極曲線 
伴い, $E_{2}$ で不働態化される。12 $\mathrm{N}$ と $16 \mathrm{~N} \mathrm{H}_{2} \mathrm{SO}_{4}$ 中で も $10 \mathrm{~N}$ 中とほほ同じ電位で不働態化されるが，12N, $16 \mathrm{NH}_{2} \mathrm{SO}_{4}$ 中での不働態化電位は $E_{3}$ であると思われ る。すなわち $E_{3}$ は $0.6 \mathrm{~V}$ 付近であるのが普通である が，酸化物の陽分極曲線のところでも述べたこの濃度に おける異常現象のために早方向にずれたものと思われ る。また $16 \mathrm{~N} \mathrm{H}_{2} \mathrm{SO}_{4}$ になると活性領域の電流が著しく 隇少する。図 6 亿 $20 \mathrm{~N}, 24 \mathrm{~N}, 32 \mathrm{~N}, 36 \mathrm{~N} \mathrm{H}_{2} \mathrm{SO}_{4}$ 中で 得られた純鉄の陽極分極曲線を示す。 $20 \mathrm{~N}$ 以上の濃度

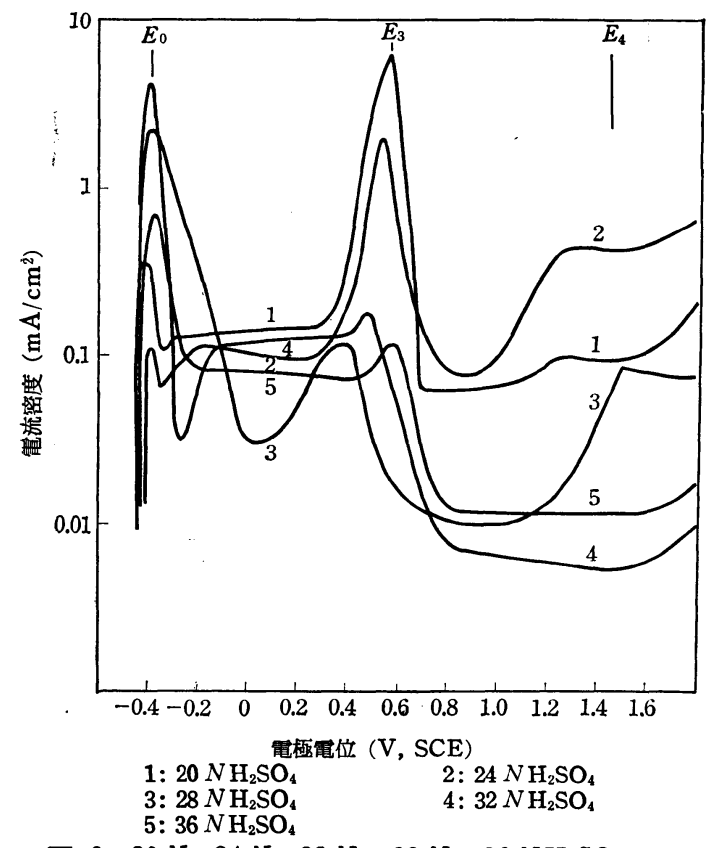

図 $620 \mathrm{~N}, 24 \mathrm{~N}, 28 \mathrm{~N}, 32 \mathrm{~N}, 36 \mathrm{NH}_{2} \mathrm{SO}_{4}$ 中に おける純鉄の陽極分極曲線

になると $E_{1}, E_{2}$ が認められなくなるが， $E_{3}$ のピークは 明確となり, 特に $20 \mathrm{~N}, 24 \mathrm{~N} \mathrm{H}_{2} \mathrm{SO}_{4}$ 中において著しく 大きくなる。 $28 \mathrm{~N} \mathrm{H}_{2} \mathrm{SO}_{4}$ 中では他の濃度の硫酸中とは かなり異なった挙動を示している。なお, 酸化物および 純鉄の陽分極曲線はかなり複雑であるが，その再現性は ピークの位置については良く, 電流值についても相対値 はかなり良いものである。

\section{4. 考察}

前報1)で報告した希薄な硫酸中で認められた小さなピ 一クが高濃度の硫酸中で明瞭となり，前報で検討した鉄 の酸化還元電位を確認することができたが，この硫酸濃 度による分極特性の変化は, 濃度変化による硫酸の性質 変化と密接な関係があるものと考えられる。すなわち硫 酸の濃度が变ると $\mathrm{H}^{+}$イオン, $\mathrm{HSO}_{4}^{-}$イオン, $\mathrm{SO}_{4}^{2-}$ イオン 濃度が变わり, 硫酸濃度が非常に高くなると非解離の硫 酸も出現するので, 筆者らの求めた分極曲線にはこれら の影響が交錯してはいってきているものと思われる。図

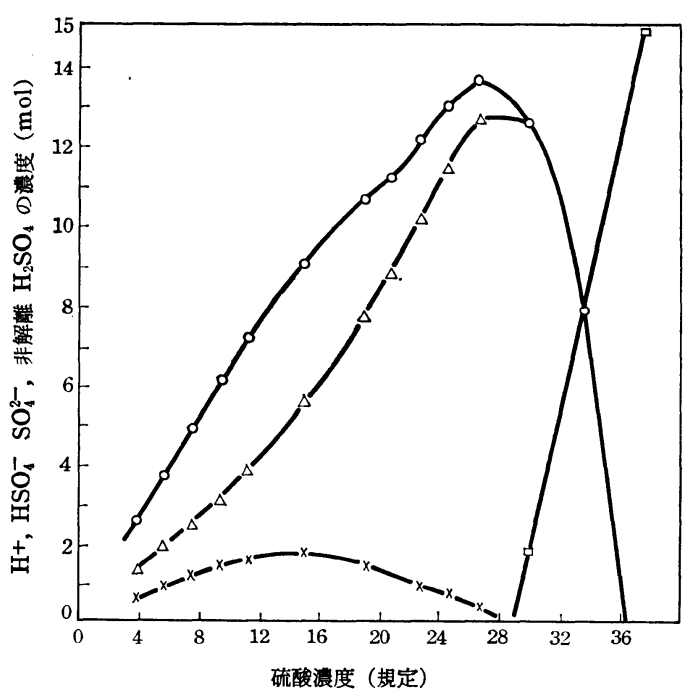

$\mathrm{O}: \mathrm{H}^{+}, \triangle: \mathrm{HSO}_{4}^{-}, \times: \mathrm{SO}_{4}^{2-}, \square: \mathrm{H}_{2} \mathrm{SO}_{4}$

図 7 硫酸謈度変化に上る $\mathrm{H}^{+}, \mathrm{HSO}_{4}^{-}, \mathrm{SO}_{4}^{-2}$, 非解離 硫酸の濃度变化 (T.F. Young6) による)

7 はT.F. Young が求めた種々の濃度の硫酸中に存在す る $\mathrm{H}^{+}$イオン, $\mathrm{HSO}_{4}^{-}$イオン, $\mathrm{SO}_{4}^{2-}$ イオンおよび非解離の $\mathrm{H}_{2} \mathrm{SO}_{4}$ の濃度を図示したものである。これによると $\mathrm{H}^{+}$ イオンと $\mathrm{HSO}_{4}^{-}$イオンの濃度は $26 \mathrm{~N} \mathrm{H}_{2} \mathrm{SO}_{4}$ 付近で, $\mathrm{SO}_{4}^{2-}$ イオン濃度は $12 \sim 15 \mathrm{~N} \mathrm{H}_{2} \mathrm{SO}_{4}$ 付近でそれぞれ極 大值を取り, 非解離の $\mathrm{H}_{2} \mathrm{SO}_{4}$ は $28 \mathrm{~N} \mathrm{H}_{2} \mathrm{SO}_{4}$ 以上の濃 度で急激に増加している。图 8 は硫酸濃度变化に対する 純鉄の自然電極電位の変化を図示したものである。この

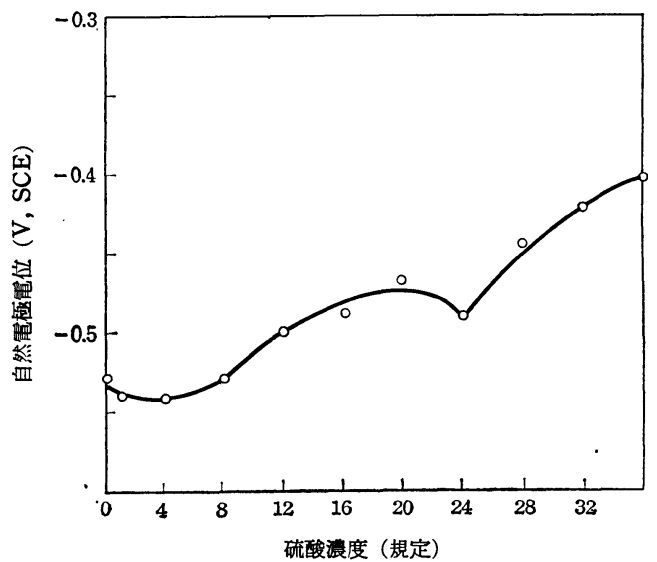

図 8 純鉄の自然電極電位に及ぼす硫酸濃度の影響

結果は硫酸濃度の増加にほぼ比例して自然電極電位が貴 電位へ移行することを示している。このことと各イオン 濃度との関係を述べることはむずかしいが $\mathrm{H}^{+}$イオン濃 度の極大点であるとともに，非解離 $\mathrm{H}_{2} \mathrm{SO}_{4}$ が出現する 濃度に近い $24 N$ 付近に不連続点が認められることから 自然電極電位は，この濃度以下では $\mathrm{H}^{+}$イオン濃度また 
は $\mathrm{HSO}_{4}^{-}$イオン濃度, これ以上では非解離 $\mathrm{H}_{2} \mathrm{SO}_{4}$ に影 響を受けているものと解釈できる。一方 $\mathrm{FeO}_{1.0}$ の自然 電極電位は $4 N \sim 16 N$ の濃度で純鉄に近い低い值を示 乙, かつこの濃度範囲では純鉄と同㥞, 分極曲線上に硫 酸塩形成に対応する電位之思われる $E_{0}$ が出現する。こ の原因湖らかでないが, この濃度範囲は $\mathrm{SO}_{4}^{2-}$ イオ ンが存在する濃度範囲にあるので, $\mathrm{SO}_{4}^{2-}$ イオンの影響 も大きく受けているものと考えられる。図 9 は $E_{1}, E_{2}$, $E_{3}, E_{4}$ の各電位における電流值および不働態領域の $0.8 \mathrm{~V}$ にお汀る不働態保持電流の硫酸濃度による変化を 図示したものである。これによると，どの電位における

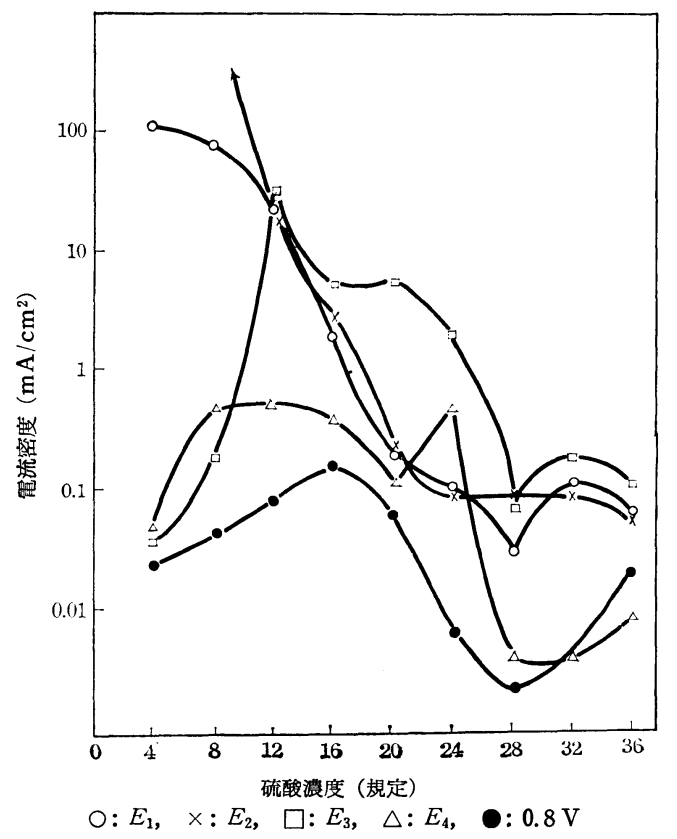

図 9 純鉄の $E_{1}, E_{2}, E_{3}, E_{4}$ おょび $0.8 \mathrm{~V}$ での電 流值に及ぼす硫酸濃度の影響

電流值む $\mathrm{H}^{+}$イオンと $\mathrm{HSO}_{4}^{-}$イオン濃度が極大を示す $28 N$ 付近で極小值を示しており, $E_{1}, E_{2}$ の電流值はこの 濃度まで濃度増加とともに単調に減少しているが, $E_{3}$, $E_{4}$ の電流值と不働態保持電流は, いずれも $\mathrm{SO}_{4}^{2-}$ イオン 濃度が極大を示す $12 \sim 24 N$ の間で極大を示している。 このことは $E_{1}$ と $E_{2}$ の電流值は主として $\mathrm{H}^{+}$イオンま たは $\mathrm{HSO}_{4}^{-}$イオンの影響を受け， $E_{3}$ と $E_{4}$ 並びに不働 態化保持電流主として $\mathrm{SO}_{4}^{2-}$ イオンの影響をうけるも のと考えられる。活性領域に存在する $\mathrm{Fe} / \mathrm{FeO}_{1.05}$ と $\mathrm{FeO}_{1.05} / \mathrm{FeO}_{1.1}$ の酸化還元電位である $E_{1}$ と $E_{2}$ におけ る溶解電流が $\mathrm{H}^{+}$イオンまたは $\mathrm{HSO}_{4}^{-}$イオン濃度に影
響され，不働態領域に存在する $\mathrm{FeO}_{1.1} / \mathrm{Fe}_{3} \mathrm{O}_{4}$ と $\mathrm{Fe}_{3} \mathrm{O}_{4} /$ $\mathrm{Fe}_{2} \mathrm{O}_{3}$ の酸化還元電位である $E_{3}$ と $E_{4}$ における溶解電 流が $\mathrm{SO}_{4}^{2-}$ イオン濃度に影響されることは興味深いこと である。また実験結果の所でも述べたように $E_{0}, E_{4}$ を 除く他の三つのピークの現われる電位のうち, $E_{1}$ と $E_{2}$ が $12 \mathrm{~N} \mathrm{H}_{2} \mathrm{SO}_{4}$ で, $E_{3}$ が $12 \mathrm{~N} 16 \mathrm{~N}$ と $28 \mathrm{NH}_{2} \mathrm{SO}_{4}$ で 星方向に移行し, 他の濃度の硫酸中と異なった挙動を示 すことも，これらの濃度が $\mathrm{SO}_{4}^{2-}$ イオン, $\mathrm{H}^{+}$イオン濃 度のそれぞれの極大を示す濃度と一致することからみて 興味ある事実であるが，これらイオンの影響を別々に調 べることができないので説明は困難である。

\section{5. 結}

論

純鉄および鉄酸化物について $0.1 N \sim 36 \mathrm{~N} \mathrm{H}_{2} \mathrm{SO}_{4}$ 中 の陽極挙動を調べ次の結果を得た。

(1) 純鉄注 $E_{0}, E_{1}, E_{2}, E_{3}, E_{4}$ の五つの電位で電流 のピークを示すことを鉄酸化物と比較検討することによ り確認した。これらの電位は硫酸濃度の影響を余り受け ず，そ机ぞれ $-0.4 \mathrm{~V},-0.1 \mathrm{~V}, 0.3 \mathrm{~V}, 0.6 \mathrm{~V}, 1.4 \mathrm{~V}$ 付近に存在するが, 硫酸濃度 $12 N \sim 16 N$ では $E_{1}, E_{2}$, $E_{3}$ が电方向にずれる。更にこれらの各電位における各 電流のピークの高さは硫酸濃度とともに複雑に変わる が，これは硫酸中の $\mathrm{H}^{+}, \mathrm{HSO}_{4}^{-}, \mathrm{SO}_{4}^{2-}$ イオンあるいは 非解離 $\mathrm{H}_{2} \mathrm{SO}_{4}$ 濃度と密接な関係があるようである。

(2) 純鉄の不働態化電位は $1 \mathrm{~N} \sim 10 \mathrm{~N} \mathrm{H}_{2} \mathrm{SO}_{4}$ 中では $E_{2}$ によって決定されるが, これ以上の濃度の硫酸中で は $E_{3}$ によって決定される。しかしながら $16 \mathrm{~N}$ 以上の 硫酸中では $E_{0} \sim E_{3}$ 電位領域でも溶解電流はかなり小さ w。

（3）純鉄の不働態保持電流は $\mathrm{SO}_{4}^{2-}$ イオンによって著 しい影響を受け, $\mathrm{SO}_{4}^{2-}$ イオン濃度が高いほど電流值は 大きい。

終りに, 本研究の発表を許可された三菱原子力工業株 式会社研究所大井上博所長杉本一六副所長に厚く感謝す る次第である。

（昭和 40 年 1 月 14 日受理）

\section{文献}

1）前川, 中島: 日本金属学会誌, 28, No. 11, 684 688 (1964) Nov.

2) M. Nagayama \& M. Cohen: J. Electrochem. Soc., 110, No. 6, 670 679 (1963) June

3）塩原, 沢田, 森岡: 日本金属学会誌, 28, No. 1, 6 11(1964) Jan.

4) W. P. Banks \& J. D. Sudbury: Corrosion, 19, No. 9, $300 \mathrm{t} \sim 309 \mathrm{t}$ (1963) Sept

5) L.S. Darken \& R.W Gurrey: J. Am.Chem. Soc., 68, No. 5, 798 816 (1946) May

6) T. F. Young: Record Chem. Prog., 12, No. 2, 81 95 (1951) 